\title{
THE LATEST DATED HISTORICAL RECORD OF THE WILDCAT (FELIS SILVESTRIS) FROM CRIMEA
}

\author{
Pavel Gol'din, Elena Gladilina, Dmitry Startsev
}

Schmalhausen Institute of Zoology, National Academy of Sciences of Ukraine

E-mail: pavelgoldin412@gmail.com

The Latest Dated Historical Record of the Wildcat (Felis silvestris) from Crimea. — Gol'din, P., Gladilina, E., Startsev, D. - The wildcat became extinct in Crimea. The specimen reported here, a sub-complete skeleton, was collected in 2013 on the archaeological site of Neyzats (Neusatz) and dated to ca. 1600 years BP. It differs from domestic cats with its large body and skull size, nasal and orbit anatomy, and therefore is identified as a wildcat. In the skull size and proportions, as well as in the nasal shape, it generally fits the Caucasian population of European wildcats Felis silvestris silvestris. The shape of presphenoid also fits well the Asian wildcat Felis silvestris ornata or the African wildcat Felis silvestris lybica; however, the posterior extension of nasals is the distinct trait of European or Caucasian cats. There are two main ideas to explain this unusual morphology. On the one hand, the Crimean cat can be a hybrid of the Caucasian and the domestic cat (which originates from F. s. lybica) showing the heterosis. On the other hand, it can be a member of an ancestral population with the archaic mixed features of both subspecies. Thus, the genetic relationships of wildcats in this region, as well as their taxonomy, are worth to be examined and revised with regard to their history and geographical position within the species range.

Key words: wildcat, Crimea, Holocene.

Найпізніша датована історична знахідка кота лісового (Felis silvestris) 3 Криму. - Гольдін, П., Гладиліна, О., Старцев, Д. - Лісовий кіт є зниклим видом для Криму. Екземпляр, відомості про якого наведені у статті, - майже повний скелет, знайдений 2013 р. в археологічному місцезнаходженні Нейзац і датований віком 1600 років. Він відрізняється від свійських котів великими розмірами тіла і черепа, анатомією носових кісток і глазниць, i тому визначений як дикий кіт. За розміром $\mathrm{i}$ пропорціями черепа, як і за формою носових кісток, він в цілому відповідає діагнозу кавказької популяції європейського підвида Felis silvestris silvestris. За формою пресфеноіда він добре відповідає діагнозам азійського і африканського підвидів Felis silvestris ornata і Felis silvestris lybica; але видовжені назад носові кістки - це характерна риса саме європейських і кавказьких котів. Ця незвична морфологія може бути пояснена двома гіпотезами. По-перше, кримський кіт може бути гібрідом кавказького i свійського кота (який походить від F. s. lybica) з ознаками гетерозісу. По-друге, він може бути представником предкової популяції з архаїчними змішаними рисами обох підвидів. Таким чином, генетичні відносини котів в цьому регіоні, як і їх таксономія, мають бути досліджені і переглянуті 3 урахуванням їх історії і географічного розташування в ареалі виду.

Ключові слова: кіт лісовий, Крим, голоцен.

\section{Introduction}

The Crimean peninsula lost much of its natural fauna of large and medium-sized carnivores during the past several millennia: among the extinct species, there were the brown bear, lynx, corsac and wolf (which now re-colonized Crimea); the range of the badger shrank to the mountainous areas. The wildcat was recorded from the late Pleistocene (ca. 47-33 kya) and the early Holocene (ca. 11.6-7.5 kya) of the Crimean Mountains (Sommer, Benecke, 2006; Ridush et al., 2013).

The undated Holocene record came from the Skelya cave in the south-western Crimea (Бачинський, Дублянський, 1962), and another sub-Atlantic record (<1000 BCE) came from Emine-BairKhosar cave in the central Crimean mountains (Ridush et al., 2013). 
Here we report a zooarchaeological record of the wildcat as an exceptionally well preserved skeleton with a clear chronological context.

\section{Archaeological setting}

The specimen of the cat was collected by I. N. Khrapunov (Taurida National University) in 2013 on the archaeological site of Neyzats (Neusatz) on the right bank of the Zuya River south to

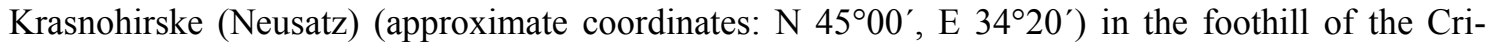
mean mountains. The site is a well stratified Sarmatian and Alanian cemetery of 2-5 centuries CE, with the upper horizon (where the specimen was found) dated between the late $300 \mathrm{~s}$ and early $400 \mathrm{~s}$ CE based on numerous artifacts (for the detailed description, see: Храпунов, 2011); thus, the specimen in question is tentatively dated to $400 \mathrm{CE}$. The cat skeleton was found on an altar, which implies it was the offering of a possibly unusual animal. The tail was missing, and it was likely to be removed.

\section{Description of the specimen}

The specimen (now exhibited on display in the Zoological Museum of Taurida National University in Simferopol) is presented as a sub-complete skeleton consisting of the skull with the teeth in situ and mandibles, vertebrae (including 6 first cervical vertebrae, 9 thoracic vertebrae [the $7^{\text {th }}$ cervical and the first four thoracic are missing], 7 lumbar vertebrae and partial sacrum), scapulae, sub-complete sets of forelimb bones (phalanges are mostly missing), innominates and sub-complete sets of hindlimb bones (fig. 1). Based on the cranial, vertebral and pelvic anatomy, it is identified as an adult, physically mature male. However, the skull sutures are unfused and the teeth are unworn, which indicates its relatively young age. Cranial and postcranial measurements $(n=14)$ were taken following Ognev (Огнев, 1935) and Yamaguchi et al. (2004).

The skull is long and wide (tab. 1, fig. 2) with especially elongated tooth rows and cheek teeth. The nasals are long and flat, and they extend posterior to the margins of maxillae. The anterior margin of the nasal is deeply notched, with a medial embayment, and there is a pit in its proximal portion. The presphenoid is narrow, with a rhomboid widening in its anterior portion (fig. 3).

\section{Discussion}

The cat from Crimea differs from domestic cats with its large body and skull size, flat pitted posteriorly extended nasals and open, laterally facing orbit (Огнев, 1935). Therefore, we identify it as the wildcat Felis silvestris Schreber, 1777. Thus, this is the latest record of wildcats from Crimea with an exact dating, ca. $400 \mathrm{CE}$.

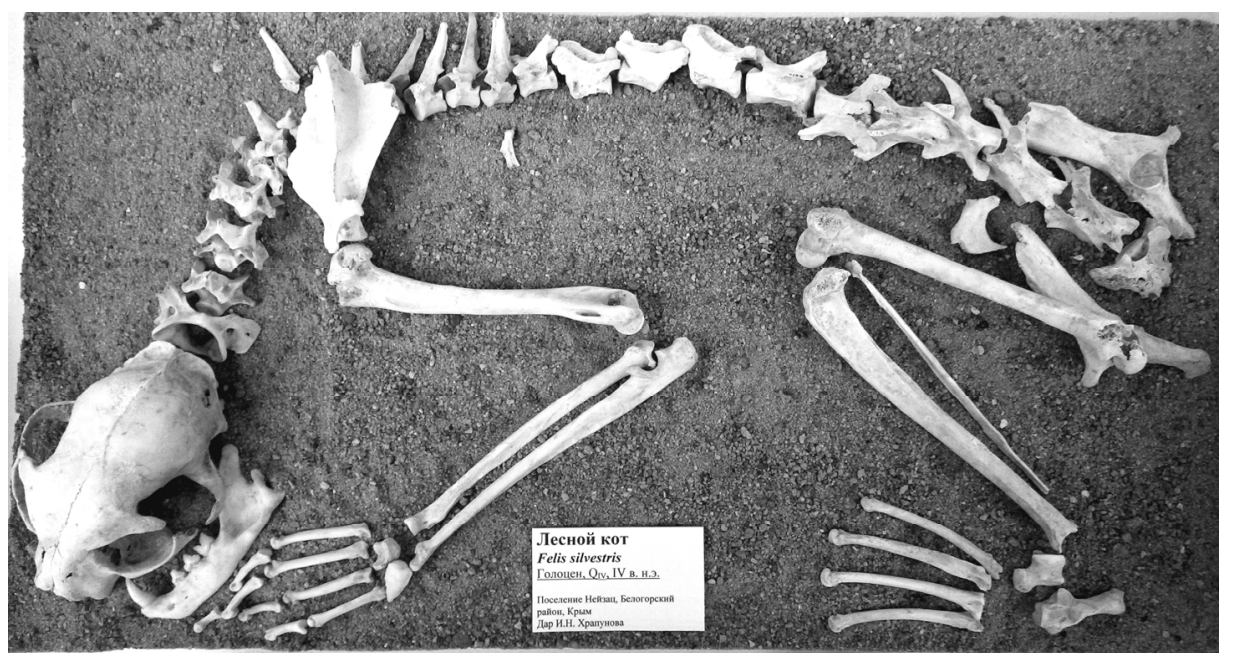

Fig. 1. General view of the skeleton of the wildcat from Crimea.

Рис. 1. Загальний вигляд скелету кота лісового з Криму. 
Table 1. Skeletal measurements of the wildcat from Crimea

Таблиця 1. Виміри скелету кота лісового з Криму

\begin{tabular}{lcclcc}
\hline Measurement & Distance $(\mathrm{mm})$ & & Measurement & Distance $(\mathrm{mm})$ \\
\cline { 1 - 2 } Condylobasal length & 98.5 & & Medial length of the nasal & 25.3 \\
Zygomatic width & 79.0 & & Palatal width & 30.0 \\
Parietal width & 53.5 & & Pm2+Pm3 length & 19.5 \\
Orbit length & 30.0 & & Pm2-Pm4 length & 24.1 \\
Length of the auditory bulla & 22.9 & & Mandible length & 71.7 \\
Width of the auditory bulla & 14.6 & & Length of the humerus & 124.0 \\
Length of the upper tooth row & 43.0 & & Length of the femur & 138.5 \\
\hline
\end{tabular}

The cat from Crimea differs from the European wildcat Felis silvestris silvestris with the long and wide skull, especially with long facial portion, teeth, auditory bullae, and notched and pitted nasals (fig. 2, 3): these differences lie beyond the limits of individual variation of modern cats from the eastern Europe (Огнев, 1935).

In the skull size and proportions, as well as in the nasal shape, it generally fits the Caucasian population of the European wildcats which is sometimes referred to as a separate subspecies Felis silvestris caucasicus Satunin, 1905, but its skull is unusually wide and long-snouted even for the Caucasian cats (see the measurements in: Огнев, 1935). The skull proportions, nasal shape and, more importantly, the shape of presphenoid (fig. 3) well fit the Asian wildcat Felis silvestris ornata Gray, 1830 or, possibly, the African wildcat Felis silvestris lybica Forster, 1780 (the latter is also supported by the shape of the mandible margin). However, the posterior extension of nasals is the distinct trait of Felis silvestris silvestris, whether European or Caucasian cats (Огнев, 1935; Yаmaguchi et al., 2004).

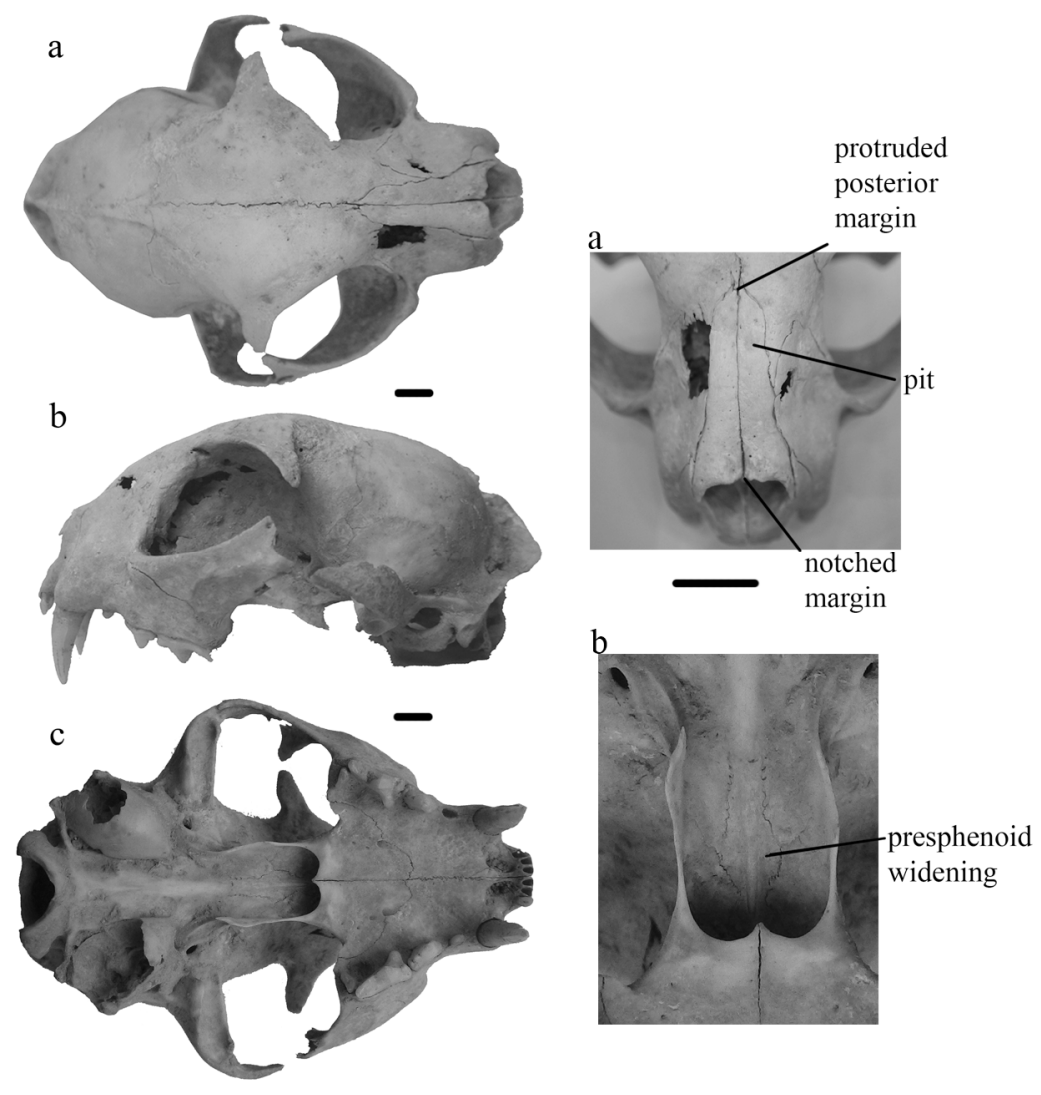

Fig. 2 (left). Skull of the wildcat from Crimea: $a$, dorsal view;

$b$, lateral view; $c$, ventral view.

Рис. 2 (ліворуч). Череп кота дикого з Криму:

$a$ - вид зверху;

$b$ - вид збоку;

$c$ - вид знизу.

Fig. 3 (right). Distinctive traits of the skull of the wildcat from Crimea: $a$, nasals; $b$, presphenoid.

Scale bars equal $1 \mathrm{~cm}$.

Рис. 3 (праворуч). Відмінні риси черепа кота дикого 3 Криму:

$a$ - носові кістки; $b$ - пресфеноїд.

Мірило - 1 см. 
There are two main ideas to explain this unusual morphology. On the one hand, the Crimean cat can be a hybrid of the Caucasian and the domestic cat (which originates from $F$. s. lybica) showing the heterosis: it explains both the large size and the combination of caucasicus and lybica features. On the other hand, it can be a member of an ancestral population with the archaic mixed features of both subspecies which, in its turn, can be related to the Caucasian cats: now Caucasian populations inhabit the bordering area between the ranges of $F$. s. silvestris (occurring in Asia Minor), $F$. s. or$n a t a$ and $F$. s. lybica. Noteworthy, both explanations suggest rather the Caucasian and not the European affinities of the Crimean cat.

Paleontological records indicate the strong postglacial northward expansion of the range of the European wildcats, which survived the latest glaciation in the Mediterranean refugium. However, there are neither prehistorical, nor historical records of wildcats on the Dnieper left bank and in the northern Crimea and, thus, no evidences for the connection of the European and Crimean ranges (Sommer, Benecke, 2006). On the contrary, there are both Pleistocene and Holocene records of wildcats in the mountainous Crimea allowing to suggest this region as a hypothetical Pleistocene refugium for this species, as well as for some other temperate mammalian species (Stankovic et al., 2011). Our record of a specimen, which is similar to the Caucasian wildcats, supports the idea about a local relic population, which should be tested by further genetic research. Meanwhile, the genetic relationships of Caucasian wildcats, as well as their taxonomy, are worth to be examined and revised with regard to their history and geographical position within the species range.

\section{Acknowledgments}

We thank to I. N. Khrapunov who provided the specimen for the study and an anonymous reviewer for the comments to the manuscript.

\section{References}

Бачинський Г. О., Дублянський В. М. Палеозоологічна характеристика деяких глибинних карстових порожнин Гірського Криму // Зб. праць Зоол. музею. - 1962. — № 31. — С. 43-51.

[Bachinsky, G. O., Dublyansky, V. M. Paleozoological characteristics of some deep karst cavities of the Mountainous Crimea // Zbirnyk Prats Zoologichnogo Muzeyu. — 1962. — N 31. — P. 43-51. (In Ukr.).]

Храпунов, И. Н. (ред.). Исследования могильника Нейзац : Сб. научн. ст. - Симферополь : ДОЛЯ, 2011. $274 \mathrm{c}$.

[Khrapunov, I. N. (ed). Exploring The Cemetery of Neyzats. — Simferopol : Dolya, 2011. — 274 p. (In Rus.).]

Огнев, С. И. Звери СССР и прилежащих стран. Хищные и ластоногие. (1935). - 752 с.

[Ognev, S. I. The Mammals of USSR And Adjacent Countries. Vol. 3. Carnivores And Pinnipeds - Moscow, Leningrad : Glav. Izdat. Biol. i Med. Liter., 1935. — 752 p. (In Rus.).]

Ridush, B., Stefaniak, K., Socha, P. et al. Emine-Bair-Khosar Cave in the Crimea, a huge bone accumulation of Late Pleistocene fauna // Quaternary International. — 2013. - Vol. 284. - P. 151-160.

Sommer, R. S., Benecke, N. Late Pleistocene and Holocene development of the felid fauna (Felidae) of Europe: a review // Journal of Zoology. - 2006. - Vol. 269 (1). - P. 7-19.

Stankovic, A., Doan, K., Mackiewicz, P. et al. First ancient DNA sequences of the Late Pleistocene red deer (Cervus elaphus) from the Crimea, Ukraine // Quaternary International. — 2011. - Vol. 245. - P. 262-267.

Yamaguchi, N., Driscoll, C. A., Kitchener, A. C. et al. Craniological differentiation between European wildcats (Felis silvestris silvestris), African wildcats (F. s. lybica) and Asian wildcats (F. s. ornata): implications for their evolution and conservation // Biological Journal of the Linnean Society. — 2004. — Vol. 83 (1). — P. 47-63. 